\title{
AMIKOR AZ ELMÉLET HASZNÁLHATÓ A GYAKORLATBAN: NÉHÁNY OROSZ POSZT-VIGOTSZKIÁNUS FEJLESZTÉSI MEGKÖZELÍTÉS ALKALMAZÁSA A TANÁRI FELADATOKBAN
}

\author{
ANDREI I. PODOLSKIJ \\ a Moszkvai Állami Egyetem \\ egyetemi tanára \\ apodolskij@mail.su
}

\section{Az elmélet gyakorlati alkalmazásának szükségességéről és lehetőségéről}

Az egyik legfontosabb és legélesebben vitatott kérdés a tudományos eredményekkel kapcsolatban, hogy mennyire használhatók fel a gyakorlatban és milyen eredménnyel. Azt, hogy a pszichológia tudományának eredményei mennyire alkalmazhatók az iskolák különböző típusaiban, a képzés, az oktatás különböző eseteiben, jól illusztrálja, hogy e probléma megoldása jelenleg hol tart. A tanulmány fó céljai a következök:

1. Megvizsgálni, hogy milyen lehetőségek vannak és milyen nehézségek vetődnek fel, amikor a pszichológia eredményeit alkalmazni akarjuk a gyakorlatban.

2. Megvizsgálni, hogy milyen okok állnak a felhasználás sikere vagy kudarca mögött.

3. Felvázolni az utat egy olyan alkalmazott pszichopedagógiai elmélet kidolgozása felé, amely át tudná hidalni a szakadékot a pszichológiai elmélet, főleg tanulás- és a fejlődéslélektan, valamint az oktatás, a képzés, az iskolázás gyakorlata között.

A fenti célokhoz kapcsolódóan elsősorban azt szeretném vizsgálni, hogy milyen problémák vetödhetnek fel a gyakorlatban, amikor a Galperin által kidolgozott értelmi cselekvések szakaszos fejlesztésének elméletét alkalmazzák.

Az már valószínúleg teljesen triviális, hogy kapcsolódási pontok vannak a pszichológia és a nevelés-, valamint az oktatáselmélet között. Azonban nem annyira elfogadott és általános, hogy vizsgáljuk a köztük fennálló funkcionális összefüggéseket. Ha a tanárokat, trénereket és más oktatókat a pszichológia tudományos eredményeinek fogyasztóiként fogjuk fel, akkor fel kell tennünk a következő kérdést: a gyakorló szakembereknek milyen pszichológiára van szükségük? Minden bizonnyal 
nem spekulációkra, hanem olyan konkrét tudásra a tanulás-, a fejlődés- és az oktatáslélektan területéröl, amely a gyakorlati tevékenységük alapját képezheti.

Azt is mondhatjuk, hogy az oktatás gyakorlata nagy kihívást támaszt a pszichológia tudományával szemben. A kihívás abban áll, hogy olyan tudást kell biztosítania, amely egyrészt érzékeny annak a társadalmi kontextusnak az egyre növekvő heterogenitására és komplexitására, amelyben a tanulási folyamatok végbemennek, másrészt pedig, amely konkrét és világos pszichológiai leírást, információt ad a tanulókról, a tanulási/tanítási folyamatokról és tartalmakról a pedagógusok számára. Ha ennek a kihívásnak nem tudunk megfelelni, akkor a tudósok továbbra is töprenghetnek azon, hogy a tanárok és iskolavezetők miért nem akarják használni jelentős, sokszor kiemelkedő eredményeiket, modelljeiket, elméleteiket. A tanárok, az iskolavezetők és a közvélemény pedig továbbra is csodálkozhat azon, hogy miért nem tudnak a tudósok konkrét, hasznos, közérthetö, világos, az iskolai mindennapokban jól használható tudással szolgálni.

Több mint 20 évvel ezelőtt Snelbecker kiadott egy összefoglaló listát a pedagógusok érveiről, amelyekkel azt magyarázták, hogy mindennapi tevékenységükben miért nem használják az oktatáspszichológusok és az oktatáselméleti szakemberek elöírásait. Egyesek elismerték, hogy bár a javaslatok innovatívak, de úgy vélték, nem kivitelezhetőek az ő osztálytermükben. Másoknál a következő vélemény jelent meg: „Ha alkalmazom, amit javasolnak, teljesen meg kell változtatnom a gyakorlatomat”. Gyakoriak voltak a következő érvek is: „Nincs nekem szükségem semmiféle képzésre.” „Már csinálom, amit javasolnak.” „Már ismerem ezeket az elméleteket." (Snelbecker, 1987)

\section{Galperin megközelítése, mint intellektuális eljárás}

Könnyü belátni, hogy milyen nehéz megteremteni annak az előfeltételeit, hogy a tudomány által felhalmozott tudást a gyakorló szakemberek elfogadják és alkalmazzák. Ehhez ugyanis arra lenne szükség, hogy a pedagógusok, a képzők, az oktatók stb. több lehetőséget kapjanak a tudással történő megismerkedésre és annak alkalmazására, saját gyakorlatuk és a józanész alapján történő tevékenykedésre. Arra lenne szükség, hogy létezzen egy olyan általános intellektuális eljárás, amely nem csak lehetővé teszi a felhasználók számára, hogy az iskolázás konkrét feladatainak sokrétüségét a modern pszichológia (oktatáspszichológia, fejlödéslélektan) eredményeinek segítségével vizsgálják, hanem ez az irány még vonzó is legyen számukra. Más szavakkal, olyan intellektuális eszközt kellene a felhasználók kezébe adni, amelynek segítségével a gyakorló szakemberek gazdagíthatják az oktatási és képzési technológiákkal kapcsolatos kompetenciáikat.

Ennek az eljárásnak többfunkciósnak és univerzálisnak kell lennie. Rá kell irányítania a pedagógus figyelmét a tanuló tudáskonstruálási folyamatainak változásaira, fejlődésére és a tanulási folyamat mentális, belső komponenseire. Procedurális, 
technológiai szinten e megközelítésnek kellően operacionalizáltnak kell lennie, annak érdekében, hogy ne merüljön ki egy tucat spekulatív kijelentés vagy a jószándék általános megfogalmazásában. Tehát az alkalmazott oktatáspszichológiának a pszichológiai tudás szigorú, explicit formáját kell öltenie. Vagyis, nem metaforikus módon kell leírnia azokat a legfontosabb (strukturális, funkcionális és fejlődési) változókat, amelyek meghatározzák a tanulási/tanítási tevékenység hatékonyságát és a változók közötti összefüggéseket. Ezen túl részletesen, egyértelmúen le kell írnia azokat a pszichológiai szempontból meghatározó feltételeket, amelyeknek jelen kell lenniük az iskolázásban (az oktatásban és a képzésben). Egy ilyen leírásnak az egész oktatási helyzetet át kell fognia, meg kell ragadnia az oktatási folyamatok és jelenségek komplexitását.

Fontos hangsúlyozni, hogy ennek a leirásnak érzékenynek kell lennie a fejlödésre. Két fö, alapvetően eltérő mechanizmus húzódhat meg azon jelenség mögött, hogy valaki nem tud kivitelezni egy értelmi cselekvést:

1. Makrogenetikai szempontból, a tanuló mentális terve nem megfelelően fejlett (Galperin, 1992; Piaget, 1970), és ezért nem tud cselekedni a valóság bizonyos szféráiban.

2. Mikrogenetikai szempontból, azok az értelmi cselekvések, amelyek bizonyos tanulási tartalmak elsajátításának előfeltételei, egyáltalán ki sem alakultak, vagy nem megfelelö, nem elégséges módon alakultak ki a tanuló múltbeli tapasztalatai során (Galperin, 1969). Például általában nem lehet bizonyos tananyagokat elsajátítani egy bizonyos kor vagy fejlödési szakasz elérése előtt (Piaget, 1970). Azonban az efféle korhoz kötött akadályokat le lehet bontani (Galperin, 1992), ha a pedagógus elösegíti a tanuló értelmi cselekvésének speciális kibontakozását bizonyos funkcionális fejlesztési szabályszerüségek alapján.

Az oktatás tartalmának fejlődési aspektusai hasonlóképpen világosak. Amikor az alkalmazott oktatáspszichológiai leírások felhasználásáról beszélünk, két további dimenziót kell még megkülönböztetnünk. Elöször is, figyelembe kell vennünk a tanulók fejlődési szintjét, amikor oktatási terveket dolgozunk ki. Ehhez tervezzük meg, szervezzük meg a tanulási-tanítási folyamatot a makro és mikro fejlődési szabályszerüségekkel összhangban, és határozzuk meg e folyamatnak a rövid és hoszszú távú fejlődési következményeit, valamint azt, hogy tanulási/tanítási folyamat milyen mértékü hatást gyakorol a tanulók kognitív, személyes, morális, szociális és érzelmi fejlődésére. Másodszor a fejlődési változásokat úgy is lehet szemlélni, mint a tanulási/tanítási folyamat közvetlen céljait. Ezt általános, filozófiai síkon Vigotszkij így fogalmazta meg: ,a tanítás csak akkor jó, ha a fejlődés előtt jár.” (Vigotszkij, 1978)

A fentiekböl az következik, hogy az alapvető pszichológiai ismeretek megfelelő alkalmazásának két fö lépése van: 1. Egy általános, intellektuális eljárást, vagy pszichológiailag megalapozott magyarázatot és orientációs eszközt kell találnunk, 
tehát az első lépés pszichológiai aspektusai a tanulási és a fejlődési folyamatokat, illetve a folyamatok összefüggéseit érintik. 2. Meg kell találni az eljárásnak azokat a szabályait, amelyek a gyakorlat valós helyzeteiben történő alkalmazására érvényesek. E második lépés pszichológiai szempontjai elsősorban azokra a körülményekre vonatkoznak, amelyek megkönnyítik vagy behatárolják az alapvető tudás alkalmazásának lehetőségeit a mai tanulási, oktatási, képzési gyakorlatban.

Ami az első lépést illeti, szilárd meggyőződésem, hogy a Galperin (1967, 1969, 1989, 1992) által kifejlesztett, az értelmi cselekvések szakaszos fejlesztésének elmélete olyan megközelítés, amely a fent leírt intellektuális eszközzel kapcsolatos követelményeknek teljes mértékben, minden részletében és operacionalizált módon megfelel. ${ }^{1}$

Galperint a Vigotszkij (1978) nevéhez kötődő fejlődéslélektani és tanuláspszichológiai irányzat követőjének tekinthetjük. A Galperin-féle megközelítés azonban új elemeket is tartalmaz: (a) figyelembe veszi az emberi értelem természetét, kialakulását, későbbi fejlődését, filogenetikai, antropológiai és ontológiai szempontból, továbbá (b) számol azzal a pszichológiai feltételrendszerrel, amely lehetővé teszi a tudás és a készségek kialakulását a kívánatos és elöírt eredményekkel. Galperin megközelítése szerint az értelmi tevékenység olyan funkcionális struktúra, amely az egyén élete során folytonosan fejlődik, alakul. Az ember az értelmi müveletek által tervezi, szabályozza és ellenőrzi a cselekedeteit, úgy, hogy azok megfeleljenek a társadalom által elvárt viselkedésmintáknak, sztenderdeknek és értékeléseknek. Az értelmi müveletet úgy lehet és kell felfogni, mint egy komplex, sokoldalú átalakulási folyamat végtermékét, amelyet bizonyos eszközökkel végrehajtott külső folyamatok índítanak el, vagyis a konkrét értelmi müveletek és képzetek különböző külső folyamatok interiorizálásának eredményei (Galperin, 1967).

Galperin megközelítésének bemutatására az elmélet egymással összefüggő, de mégis viszonylag független részei kapcsán rámutatunk az értelmi tevékenységek elsődleges és másodlagos tulajdonságaira, majd leírjuk azt a pszichológiai feltételrendszert, amely lehetővé teszi az értelmi tevékenységek kívánatos és az elöírt eredményeknek megfelelő formálódását.

\section{Az értelmi cselekvések elsödleges és másodlagos tulajdonságai}

A következő tulajdonságokat tartjuk elsődlegesnek: (a) a cselekvés objektív tartalmának összetételét; (b) a problémahelyzet releváns és nem releváns vonásainak megkülönböztetését, illetve ennek mértékét; (c) a művelet interiorizáltságának fokát; (d) az „energetikai” (sebesség és erő) paramétereket. A másodlagos tulajdonságok a következők: (a) ésszerüség; (b) általánosítás; (c) tudatosság; (d) kritika. A másodlagos tulajdonságok az elsődleges tulajdonságok specifikus kombinációinak

\footnotetext{
${ }^{1}$ E megközelítés leírása elöször 1952-ben jelent meg oroszul, majd egy többé kevésbé átfogó leírása 1967-ben angolul. Magyar nyelvü összefoglaló: Galperin-elmélet. In: Báthory és Falus, 1997, 554. o.
} 
eredményeként jönnek létre. Az elsődleges és a másodlagos tulajdonságok az emberi tevékenységek társadalmilag elismert, értékelt tulajdonságai, minden tevékenységre vonatkoznak, legyenek azok egyéniek vagy kollektívak, materiálisak vagy mentálisak. E tulajdonságok végső értékei határozzák meg azt, hogy milyen értelmi képzet vagy müvelet alakul ki. Galperin a tulajdonságok értékeire úgy tekintett, mint amelyek közvetlen eredményei az értelmi tevékenységeket kialakító körülményeknek. Ezért olyan feltételrendszert határozott meg, amely biztosítja és garantálja, hogy az értelmi múvelet vagy képzet az elöírt és megfelelő tulajdonságokkal rendelkezzék. Ezt a rendszert nevezte Galperin az értelmi tevékenységek szakaszos fejlesztésének. ${ }^{2}$

\section{Az értelmi cselekvések szakaszos fejlesztésének rendszere}

A rendszer négy alrendszert foglal magába. Azokat a feltételeket, amelyek

1. biztosítják, hogy az alany megfelelően motivált legyen az értelmi cselekvés elsajátítására;

2. biztosítják, hogy a tevékenységnek megfelelő orientációs bázisa kialakuljon;

3. támogatják a művelet közbülső, átmeneti formáinak (materiális és verbális) egymásba történő átalakulását, majd a végső átalakulást mentális tervvé;

4. elősegítik a cselekvésnek gyakorláson keresztül történő finomítását, hogy végül a cselekvés a kívánatos tulajdonságokkal rendelkezzék (Galperin, 1989).

Az első alrendszer (a motiváció feltételei) feltárja a tanulási motiváció és az internalizálási folyamatok dinamikája közötti kapcsolatokat és összefüggéseket.

A második alrendszer (az orientációs feltételek) magában foglalja azoknak a hierarchikusan szervezett komponenseknek a leírását, amelyek együttesen adják az értelmi cselekvés formálásának kereteit, és így lehetővé teszik, hogy a tanuló a problémahelyzetben megfelelően (ahogy Galperin mondja „teljesen”) orientálódni tudjon. Ezek a komponensek: a cselekvés végső eredményének reprezentációja; a közbülső termékek reprezentációja; a végső termék előállításához vezető általános terv reprezentációja; a közbülső termékek elóállításához vezető út reprezentációja; mindazoknak az eszközöknek, orientációs és végrehajtási eszközöknek a reprezentációja, amelyek a termékek előállításához szükségesek; annak a tervnek és azoknak az eszközöknek a reprezentációja, amelyek a cselekvés irányításához és esetleges korrekciójához szükségesek; az előbb felsorolt reprezentációk teljes struktúrája, amely együttesen adja egy-egy problémahelyzet szubjektív és objektív jellemzőinek reprezentációját, vagyis ,az értelmi cselekvés teljes orientációs bázisát” (Galperin, 1992).

\footnotetext{
${ }^{2}$ Angolul: Planned Stage by Stage Formation od Mental Actions', rövidítve: PSFMA rendszer.
} 
A harmadik alrendszer az interiorizáció szakaszait foglalja magába, vagy másképpen szólva a cselekvés mentális tervvé történő transzformációjának folyamatát. Galperin hat olyan alapvető interiorizálási szakaszt különböztetett meg, amelyek minden tanulási folyamat alapját képezik: 1. A cselekvés motivációs bázisának kialakulását. 2. A cselekvés orientációs bázisának kialakulását. 3. A cselekvés materiális változatának kialakulását. 4. A cselekvés külső, szociális, verbalizált formájának, vagyis a hangos beszédnek (overt speech) a kialakulását. 5. A cselekvés belső, verbális formájának, vagyis a belső beszédnek a kialakulását (covert speech). 6. A mentális cselekvés kialakulását: a végső változtatások, a finomítás, a cselekvés automatizálása és más cselekvésekkel egyidőben történő végrehajtása (Galperin, 1989).

A negyedik alrendszer a problémahelyzetek három alapvetö típusának leirását és a kialakulási folyamatok során történö kombinációik, valamint megjelenésük formáit tartalmazza. A három alapvető problématípus a következő (a) a pszichológiai típusú, amelyben a problémahelyzet fogalmi és látható, érzékelhető vonásait állítjuk szembe egymással; (b) a logikai típusú, amelyben a problémahelyzet alapvetô és nélkülözhetetlen paramétereit, elemeit állítjuk szembe a helyzet nem alapvető, csak „zajt” okozó paramétereivel; (c) és a tárgy típusú, amelyben egy specifikus cselekvés tárgyi tartalmának minden lehetséges formáját variáljuk. A különböző problématípusokat a tanulók számára is értelmezhető sorrendben mutatjuk be.

Ha a négy alrendszer harmonikusan együttmüködik, akkor olyan cselekvést eredményeznek, amely rendelkezik az elvárt és kívánatos elsődleges és másodlagos tulajdonságokkal. Vagyis a szakaszos formálás eredményeképpen egy külsőleg támogatott (externally mediated) és egymásra épülő szakaszokból álló cselekvés tisztán értelmi cselekvésként jelenik meg, azaz a tanuló egy meghatározott helyzet felmérése után a helyszínen hoz döntést.

\section{Az általános intellektuális eljárás alkalmazásának szabályai}

Ha az értelmi cselekvések szakaszos fejlesztését, mint általános intellektuális eljárást fogjuk fel, vagyis általános, pszichológiailag megalapozott magyarázó és orientáló eszközként, akkor mit tudunk mondani a lehetséges második lépésről, vagyis a valóságos tanulási és tanítási helyzetekben történő megfelelö alkalmazásának szabályairól?

Visszatekintve Galperin megközelítésének több mint ötvenéves történetére, azt látjuk, hogy a hatvanas, hetvenes, sőt még a korai nyolcvanas években is voltak olyan periódusok, amikor nagy optimizmussal tekintettek a módszer gyakorlati alkalmazására, hittek az alkalmazás hatékonyságában, hatásosságában. Számtalan kísérleti és alkalmazott kutatás bizonyította, hogy a módszer segítségével lehetséges bármely típusú iskolázás fö céljainak összességét megvalósítani:

a) Biztosítani lehet, hogy minden egyes tanuló, aki rendelkezik a szükséges előzetes tudással és készségekkel, garantáltan elsajátítsa az oktatási kurzus 
tartalmát. Mindezt anélkül lehet elérni, hogy meg kellene hosszabbítani (néha még inkább le is lehet rövidíteni) a tanulásra szánt időt, és mindez semmiféle járulékos költséggel nem jár.

b) A tudás elsajátítása és alkalmazása közötti válaszvonal minimalizálódik, sőt, akár el is tünik.

c) A tanulók képesek lesznek a tudás transzferére, nem csak a megszerzett tudást és készségeket, hanem az elsajátítás módját is transzferálni tudják új tanulási helyzetekre.

d) A tanulók egyre inkább érdeklődést mutatnak a tanulás folyamatai és a tudás iránt is.

Ha a hatvanas évektől a nyolcvanas évekig tartó szakasz publikációit összevetjük a későbbiekkel, akkor látható, hogy az elmélet alkalmazásával kapcsolatos optimizmus erősen csökkent. Sőt, ha valaki ismeri a jelenlegi vagy közelmúltbeli iskolai viszonyokat, akkor tudja, hogy az eljárás gyakorlati alkalmazása nem terjedt el. Voltak és vannak érdekes tapasztalatok a megközelítéssel kapcsolatban a világ különböző részein, amelyek az értelmi cselekvés szakaszos fejlődése gyakorlati felhasználásának sikereit, kudarcait, problémáit jól szemléltetik. Összegezve megállapítható, hogy az elmélet gyakorlati alkalmazása erösen korlátozott.

A nyilvánvaló társadalmi-gazdasági és szociálpszichológiai okok mellett, amelyek minden oktatáspszichológiai innováció elterjedését, alkalmazását befolyásolják, még egy elméleti-módszertani jellegü ok is korlátozta a Galperin-féle megközelítés alkalmazásának lehetőségeit. Megalapozottan állítható, hogy az e megközelítéssel kapcsolatban elvégzett legtöbb pszichológiai kutatás során legelőször az nyert bizonyítást, hogy a szakaszos formálás elméletének jelentős pedagógiai hozadéka van. Azonban a módszer támogatóinak lelkesedése a valóban szokatlan és nagy reményekre jogosító eredményekkel kapcsolatban egy ellenhatással is járt, ti. odavezetett, hogy sokan félreértették a Galperin módszer mibenlétét. Néha egyenesen úgy interpretálták, mintha nem is egy általános törvényszerúségeket leíró elmélet lenne, amely az értelmi cselekvések kialakulásának konkrét dinamikáját és eredményeit próbálja megmagyarázni, hanem egy sor technológiai elöírás a tanárok számára. Azonban egy ilyen értelmezés eltorzítja a valóságot, úgy tünteti fel a módszert, mintha valamiféle abszolút tudás lenne, egy afféle bölcsek köve.

A fenti gyakorlatnak egyik jellegzetes példája az ún. DELI hatás. ${ }^{3}$ Ez arra utal, hogy mi történik akkor, ha a szakaszos fejlesztési eljárást anélkül ültetetik át a gyakorlatba, hogy a felhasználók a megfelelő előkészítő lépéseken átmennének. Erre példa az a vizsgálat, amelyben egyetemi pszichológusok, munkapszichológusok és mérnökök együtt kidolgozták kiváló munkások mentális cselekvéseinek komplex kialakítási eljárását, majd több változatban kipróbálták. Munkapszichológusok alkalmazták az eljárást a munkások kiképzésére egyetemi pszichológusok felügyelete

\footnotetext{
${ }^{3}$ Decrease of Efficacy of Learning/Instruction: a tanulás-tanítás hatékonyságának csökkenése
} 
alatt, és kiderült, hogy a munkásoknak az eredeti terveknél háromszor kevesebb idő alatt sikerült a megfelelő tulajdonságokkal bíró értelmi cselekvéseket produkálni. Amikor ugyanezt a folyamatot a munkapszichológusok maguk hajtották végre, a hatékonyság jelentősen csökkent, a szükséges idő az eredetileg tervezettnél mindössze 40 százalékkal lett kevesebb. Amikor pedig a munkapszichológusok a szakmai képzőket képezték ki és ők ugyanezzel az eljárással képezték a munkásokat, már csak 21 százalék volt az időmegtakarítás. Ez sem tekinthető rossz eredménynek, de ha az előző kettővel összevetjük, akkor már nem igazán meggyőző az eredmény (Podolskij, 2007).

Mi állhat a DELI hatás mögött? Nem szabad figyelmen kívül hagynunk, hogy minden tudományos kutatás - elméleti vagy alkalmazott kutatásról legyen is szó mindig általánosan elfogadott absztrakciók rendszerére épül. Az ilyen elvont rendszeren alapuló módszerek direkt alkalmazása erősen korlátozott. A kísérleti körülmények között elért jó eredményeket a gyakorlatban, iskolai körülmények között soha nem lehet produkálni, mert azok a körülmények, amelyektől a kísérletek során elvonatkoztattunk, a gyakorlatban előtérbe kerülnek. Ez azt jelenti, hogy az elismert és feltételezett absztrakció zónájának (zone of admitted and assumed abstraction) pontos meghatározására és állandó szem előtt tartására kell törekedni, vagyis számba kell venni a kutató által ismert, de általában figyelmen kívül hagyott fontos, vagy kevésbé fontos fejlődési és/vagy tanulási változókat, meghatározó tényezőket (Podolskij, 2000). Az alkalmazott pszichopedagógiai elméletalkotásnak az is fontos elöfeltétele, hogy objektíven elemezzük a szakaszos fejlesztés alkalmazásának különböző iskolatípusokban történt sikeres és sikertelen eseteit. Fontos továbbá, hogy integratív tudással rendelkezzünk, vagyis szintetizáljuk mindazt a tudást, amit a modern tanulás- és fejlődéslélektan adhat az iskolai gyakorlat által a pszichológiai elmélettel szemben támasztott gyakorlati követelmények rendszerezett leírásával.

A tanulók igen változatos módon orientálódnak a problémahelyzetekben, az oktatási helyzet egészében, azaz a tanuló-tanár és tanuló-tanuló viszonyrendszerekben, valamint a tevékenységek orientációjának kialakulása nem lineáris, ezért nem lehet a szakaszos fejlesztési eljárásnak konstans, abszolút, direkt alkalmazásáról beszélni (Podolskij, 1997, 2008). Az értelmi cselekvések szakaszos fejlesztésének rendszere kapcsán a törvényszerü, az orientáló jelleget kell hangsúlyoznunk, ti. sikeres alkalmazása nem jelentheti a rendkívül általános, elvont procedúra szó szerinti alkalmazását, reprodukálását. ${ }^{4}$ Sokkal inkább azt jelenti, hogy kreativan kell megtervezni az oktatáshoz szükséges és elégséges pszichológiai feltételek rendszerét. Ez a kreatív tervezési folyamat a pszichológiai alapkutatások és az iskolázás, az oktatás, a képzés reálfolyamatai közé ékelődő, közbülső folyamat (Podolskij, 1993, 1997, 2009). Ez a közbülső pozíció az oktatási helyzetek három modelljének

\footnotetext{
${ }^{4}$ Ez áll bármely alapvető tudományos modell alkalmazására.
} 
egymást követő kidolgozása során operacionalizálódik. A három modell pedig a pszichológiai, a pszichológiai-pedagógiai és a technológiai modell (Podolskij, 1993, 1997).

A pszichológiai modell a következöket tartalmazza: (1) mindannak a tudásnak és készségeknek a leírása, amelyet a tanulónak el kell sajátítania értelmi cselekvések, képzetek és fogalmak vonatkozásában; (2) a tanuló sokszintü orientációs bázisa makro- és mikrostruktúrájának leírása, mert ez lesz az alapja a kialakítandó új tevékenységnek, képzetnek vagy fogalomnak; (3) azoknak a korcsoportfüggő és egyéni tanulói sajátosságoknak a leírása, amelyek relevánsak az oktatás és iskolázás szempontjából; (4) azoknak a speciális pszichológiai feltételeknek a leírása, amelyek a tervezett cselekvés formálásához szükségesek.

Világos, hogy az értelmi cselekvés szakaszos fejlesztésének különféle alkalmazásai során a pszichológiai modell különböző elemeire nagy hangsúlyt kell fektetni. Például, amikor tinédzserekkel dolgozik az ember, akkor nem bölcs dolog direkt utasításokban közölni, hogy mit és miként kell a tanulóknak végrehajtaniuk: ez paradox reakciókat válthat ki a belölük. Hasonló eredménnyel járhatunk, amikor olyan felnőttekkel dolgozunk, akik éppen lelki válságon mennek át: a tanárnak (képzőnek) meg kell találnia az oktatásnak azt a módszerét, amely a tanár és a tanuló személyes pozícióit nem veszélyezteti (Podolskij, 2009).

A pszichológiai-pedagógiai modell fö funkciója a pszichológiai modell követelményeinek kivetítése az iskola, az oktatás speciális objektív és szubjektív körülményeire. Ezek a körülmények a következőket ölelik fel: a tanulási tevékenységek szervezése, a különböző tanulásszervezési módok elosztása az órán, vagy az órák egy sorozatán, az órai és a házi feladatok aránya, az egyéni, a kiscsoportos és egész csoportos (frontális) tanulási tevékenységek aránya és eloszlása, valamint a rendelkezésre álló taneszközök (így számítógépek) felhasználása. Egy híres mondást némileg parafrazálva azt is mondhatnánk, hogy a pszichológiai-pedagógiai modell a „lehetőségek müvészete”, vagyis az optimális kompromisszum: annak a leírása, hogy a pszichológiai modell szigorú elöírásai közül mennyit és hogyan lehet megvalósítani a valóság objektív és szubjektív körülményei között. Időnként szükséges a szigorú követelményekből valamennyit feladni annak érdekében, hogy legalább egy részüket érvényesíteni lehessen, máskor, épp ellenkezőleg, le lehet győzni a hagyományos oktatási környezet ellenállását, és be lehet vezetni innovációkat.

A procedurális vagy technológiai modell a tanítási folyamat részletes leírását adja, meghatározza, hogyan kell a tananyagot egységekre bontani és időben elosztani, megadja az összes egység pontos célját és a célok elérésének eszközeit. Tartalmazza továbbá a teljes tanítási dokumentációt: a téma- és óraterveket, a különböző tanulási és értékelési feladatokat, a technikai eszközök alkalmazásának sorrendjét és azoknak az oktatási anyagoknak a leírását, amelyeket az iskolázás és képzés különböző formáiban alkalmaznak. A metodikai modell a hagyományos, jól megírt tanári óravázlathoz hasonló, de mindig észben kell tartanunk, hogy ez a mo- 
dell a pszichológiai, a pszichológiai és a pedagógiai modellben felvázolt megfontolásokra épül (Podolskij, 1993, 1997).

Amikor a három modelles keretről beszélünk, fontos hangsúlyozni, hogy ez is csak egy intellektuális eszköz. Ez sem egy olyan algoritmus, amely elöírja a tanárnak, hogyan kell tanítania. Ez a keret, ha megfelelően és kifinomultan használják, lehetővé teszi a tanár számára, hogy helyesen orientálódjon, tervezzen és irányítsa magát, amikor órát tervez, amikor megszervezi és végrehajtja a különböző tanítási tevékenységeket. Más szóval, ez a keret szolgáltathatna számunkra egy olyan alkalmazott pszichopedagógiai elméletet, amely áthidalhatná a szakadékot a pszichológiai alapkutatások és az oktatási/képzési gyakorlat között.

\section{Az értelmi cselekvések szakaszos fejlesztése a gyakorlatban}

Most pedig bemutatok egy példát, hogy érthetö legyen, mikor müködik ez az eljárás, eszköz sikerrel, és mikor vall kudarcot. A bemutatásra kerülö kísérletekben kisiskolások két csoportjának figyelmét fejlesztettük. A vizsgált probléma az volt, hogy a kisgyermekek gyakran nem tudtak megfelelően koncentrálni a tanulási tevékenységek végrehajtása során. Kihagytak vagy összekevertek betüket vagy szótagokat, amikor írtak vagy összeadtak számokat, amikor világosan ott volt a mínusz jel a számtanfeladatban, vagy nem találták a különbségeket két kép között stb. Ugyanakkor, ugyanezek a tanulók általában sikeresek voltak az iskolában, jól teljesítettek, amikor például meg kellett tanulniuk és alkalmazniuk kellett különféle, a tanulási tevékenységek végrehajtásához szükséges nyelvi vagy matematikai szabályokat.

Mielőtt a konkrét kísérletekre rátérnénk, röviden felidézzük a kísérletek koncepcionális hátterét. Az oktatás szakaszos fejlesztésre orientált megközelítése mindenekelőtt azt jelenti, ahogy már az előzőekben jeleztem, hogy értelmi cselekvésként leírjuk mindazt a tudást és készségeket, amelyeket a tanulóknak el kell sajátítaniuk a megfelelő tanulási környezetben. Galperin azt feltételezte, hogy az ellenőrzés értelmi cselekvése, amely az emberi kontroll tevékenység alapvető része, képezi a tanuló figyelmének fő tartalmát (odafigyelés). Az odafigyelés és az ellenőrzés nem független folyamatok, nincsen saját, diszkrét produktumuk, eredményük a hozzájuk kapcsolt tevékenység jobb végrehajtása (Galperin, 1989). A figyelem képességének javítása azt jelenti, hogy (a) a tanulónak megfelelő motivációja alakuljon ki az ellenőrzési kompetencia megszerzésére; (b) a tanuló alakítsa ki az ellenőrzési tevékenység orientációs bázisának megfelelő sémáját; (c) interiorizálja a kezdetben külső ellenőrzési tevékenységet. (d) sajátítsa el a formálódó tevékenység kívánatos, elvárt vonásait is.

Sok olyan kísérletet végeztek (például Galperin, 1989; Podolskij, 1987, 1989), ahol az alanyok harmadik, negyedik, ötödik évfolyamos tanulók voltak, mind olyanok, akik figyelmetlenség miatt sok hibát követtek el. A kísérletek során megfelelö motivációt biztosítottunk számukra: bemutattuk nekik, hogy a figyelmetlenség ho- 
gyan rontja a végső produktum minőségét, az írásművét, a matematikai feladat megoldását. A továbbiakban - a problémáról folytatott csoportos megbeszélés során - a gyerekek megismerkedtek egy olyan ellenőrzési orientációs bázis sémával, amely demonstrálta számukra, hogy mit kell tenniük, ha le akarják győzni a figyelmetlenségüket. Ezt a sémát a tanulók a tanárral közösen dolgozták ki, ami nem volt más, mint egy összefüggő szabályrendszer, amely elöírta, mit kell ellenőrizni és hogyan. Minden diák kapott egy sémát ábrázoló táblázatot, amelyet a különbözö feladatok megoldása során használt. Például amikor lemásolt egy korrekt szöveget, vagy amikor lemásolt, majd kijavított egy hibás szöveget, vagy amikor diktálás után írt, vagy amikor diktálás után írta és egyidejüleg javította is a szöveget stb. Miközben a tanulók végrehajtottak különböző ellenőrzési feladatokat (lásd: az értelmi cselekvés szakaszos fejlesztésének negyedik alrendszerét) a tanár állandó irányítása mellett, megváltoztatták viselkedésüket. Az ellenőrzésre eleinte külső, materializált formában került sor, vagyis úgy oldották meg a feladatokat, hogy a táblázat a szemük elött volt, majd ezt felváltották az internalizált ellenőrzési formák (lásd a szakaszos fejlesztés harmadik alrendszerét). A végső szakaszban a tanulók úgy hajtották végre a fö feladatot (írás, számtani feladat), hogy közben állandóan ellenőrizték és javították a munkájukat. Végül az ellenőrzési feladat egy ideális formája rögzült bennük.

A tízéves gyerekek ellenőrzési tevékenységének formálásánál alkalmazott szakaszos fejlesztés eredményeit mutatja az 1. táblázat. Az eljárás alkalmazása előtt figyelmetlen gyerekek - legalábbis a vizsgált időszakban - figyelmesebbek lettek. Azok a hibák, amelyeket figyelmetlenségböl követtek el, gyakorlatilag eltüntek iskolai füzeteikböl.

1. táblázat: A figyelmetlenségnek tulajdonítható hibák (átlagban egy feladatra számolva; n:230) (Podolskij, 1987)

\begin{tabular}{|l|c|c|}
\hline \multirow{2}{*}{\multicolumn{1}{|c|}{ FELADATOK }} & \multicolumn{2}{c|}{ Az eljárás alkalmazása } \\
\cline { 2 - 3 } & ELÖTT & UTÁN \\
\hline Hibátlan szöveg másolása során & 4,1 & 0,1 \\
\hline Hibajavítás & 3,8 & 0,1 \\
\hline Szöveg javítása minta alapján & 2,7 & 0,0 \\
\hline Szöveg leírása diktálás alapján & 5,5 & 0,4 \\
\hline Hibás szöveg egyidejü másolása és javítása & 4,4 & 0,2 \\
\hline
\end{tabular}

Ugyanezt a kísérletet végrehajtottuk 11-12 éves gyermekek körében is, akik kisgyermekkorukban beszédhibásak voltak, de a beszédhibát sikeresen leküzdötték (lásd 2. táblázat). 
2. táblázat: A figyelmetlenségnek tulajdonítható hibák (átlagban egy feladatra számolva; n:89) (Podolskij, 1987, 1997)

\begin{tabular}{|l|c|c|}
\hline \multirow{2}{*}{\multicolumn{1}{|c|}{ FELADATOK }} & \multicolumn{2}{c|}{ Az eljárás alkalmazása } \\
\cline { 2 - 3 } & ELÖTT & UTÁN \\
\hline Hibátlan szöveg másolása során & 7,2 & 1,0 \\
\hline Hibajavítás & 7,3 & 0,7 \\
\hline Szöveg javítása minta alapján & 3,3 & 0,7 \\
\hline Szöveg leírása diktálás alapján & 5,0 & 6,0 \\
\hline Hibás szöveg egyidejü másolása és javítása & 2,4 & 3,8 \\
\hline
\end{tabular}

A második táblázatból látható, hogy az első három feladat megoldásai nagymértékben javultak az eljárás alkalmazásának hatására. Az utolsó két feladat megoldásakor azonban, amelynek során nem csak egy, már megformált cselekvést kellett alkalmazni, hanem azt egy másik, fö (ez esetben az írás) tevékenység struktúrájába is integrálni kellett, az eljárás a teljesítmények romlását hozta magával. Ezért egy speciális elemzést is elvégeztünk. Ebből kiderült, hogy ezek a tanulók nem tudták az új kompetenciát önállóan alkalmazni egy új, valóságos tanulási folyamat során, úgy, ahogy az előző kísérlet alanyai. Nem tudták a kialakított cselekvés tartalmát összekötni valóságos tanulási tevékenységükkel, nem értették az ellenőrzési tevékenység lényegét, azt, hogy miért és minek kellene kialakítaniuk az ellenőrzés kompetenciáját. Ahhoz voltak szokva, hogy követik azt, amit a tanár mond nekik. Amikor a cselekvés formálása folyt, egyszerüen követték, amit a tanár által kiadott táblázat elöírt számukra. Ezzel a tanulócsoporttal lehetetlen volt úgy, együttmunkálkodva kialakítani a táblázat tartalmát, vagyis az ellenőrzési tevékenység orientációs bázisának sémáját, mint az előző csoporttal. Ez vezetett a második táblázatban látható adatsorokhoz.

A fentiekben bemutatott nehézségek kiküszöbölésére egy speciális játékos formát találtunk ki, amelyet a második csoporthoz hasonló kórtörténettel rendelkező tanulócsoportnál alkalmaztunk, annak érdekében, hogy harmonizáljuk orientációs bázisukat (Podolskij, 1997, 2008). A tanulók számára a játék feltárta a kapcsolódási pontokat az ellenőrzési tevékenység értelme (személyes értelem), egy tárgy által a tanulási folyamat során generált célok és a konkrét ellenőrzési feladat végrehajtása között. A szakaszos fejlesztés összes vonását alkalmaztuk arra az új, kiegészítő tevékenységre is, ahol nem csak a cselekvés végrehajtása volt a tevékenység formálás tárgya, mint az első csoport esetében, hanem a sokszintủ orientáció hierarchikus struktúrájának kialakítása is. A 3. táblázat mutatja, hogy milyen eredményeket értünk el az így módosított folyamat végén. 
3. táblázat: A figyelmetlenségnek tulajdonítható hibák (átlagban egy feladatra számolva; n:89) (Podolskij, 1987, 1997)

\begin{tabular}{|l|c|c|}
\hline \multirow{2}{*}{\multicolumn{1}{|c|}{ FELADAT }} & \multicolumn{2}{c|}{ A módositott eljárás } \\
\cline { 2 - 3 } & ELÖTT & UTÁN \\
\hline Hibátlan szöveg másolása során & 7,0 & 0,5 \\
\hline Hibajavítás & 7,0 & 1,0 \\
\hline Szöveg javítása minta alapján & 3,7 & 0,0 \\
\hline Szöveg leírása diktálás alapján & 7,8 & 0,3 \\
\hline Hibás szöveg egyidejü másolása és javítása & 5,8 & 0,7 \\
\hline
\end{tabular}

Ez az eset is mutatja, hogy az értelmi cselekvések szakaszos fejlesztési eljárásának betű szerinti, mechanikus alkalmazása nem feltétlenül vezet eredményre, még akkor sem, ha egy előző, hasonló esetben az alkalmazás sikeres volt. Minden alkalmazást meg kell elöznie egy olyan alapos munkának, amely feltárja a tanulók és a tananyag sajátosságait. Csak ezt az elemzést követheti a tananyag és a tanítási eljárások kidolgozása.

\section{Irodalom}

Galperin, P. J. (1969): Stages in the development of mental acts. In: Cole, M., Maltzman, I. (eds.): A Handbook of contemporary Soviet Psychology. Basic Books, New York/ London. 249-273.

Galperin, P. J. (1989): The problem of attention. Soviet Psychology, 27 (3). 83-92.

Galperin, P. J. (1992): Stage-by-stage formation as a method of psychological investigation. Journal of Russian and East European Psychology, 30 (4). 60-80.

Piaget, J. (1970): Piaget's theory. In: Mussen, P. H. (ed.): Carmichael's manual of child psychology, 1. Wiley, New York.

Podolskij, A. I. (1987): O formirovanii vnimanija: teoreticheskie i practicheskie aspecty (On formation of attention: theoretical and practical issues). University Press, Moscow.

Podolskij, A. I. (1993): Psycohological theory as base of instructional design and as part of curriculum in post-graduate education. In: Terlouw, C. (ed.): Instructional development in higher education: theory and practice. Thesis Publishers, Amsterdam. 64-80.

Podolskij, A. I. (2008): Bridging a Gap between Psychology and Instructional Practice. In: Ifenthaler, D., Pirnay-Dummer, P., Spector, J. M. (eds.): Understanding models for learning and instruction. Essays in honor of Norbert M. Seel. Springer, New York. 211-225. 
Podolskij, A. I. (2009): On scientific status and practical significance of one psychological theory. In: Zinchenko, Yu., Petrenko, V. (eds): Psychology in Russia: State of the Art. Department of Psychology MSU \&. IG-SOCIN, Moscow. 187-209.

Snelbecker, G. E. (1987): Instructional design skills for classroom teachers. Journal of Instructional Development, 10 (4). 33-40.

Vygotsky, L. S. (1978): Mind in Society. Harvard University Press, Cambridge, MA.

Fordította: Kimmel Magdolna 